\title{
Tranzicija i njezini rezultati — zašto tranzicija iz komunističkog u demokratski sustav tržišnog gospodarstva nije ostvarila očekivanja
}

\author{
Predrag Haramija*, Đuro Njavro**
}

\begin{abstract}
Sažetak
Uzrok tomu što tranzicija iz komunističkog u demokratski politički sustav nije donijela željene rezultate u gospodarstvu nalazi se u pet čimbenika: (1) naslijeđena struktura gospodarstva, odnosno prisutnost političkog utjecaja na gospodarstvo; (2) institucionalno nasljeđe komunizma (golema i neučinkovita administracija, birokratizirani pristup, prenormiranost $i$ korupcija); (3) loše provedena privatizacija; (4) nedostatna pomoć Zapada, odnosno šablonizirani pristup međunarodnih organizacija; (5) nerazvojne namjene stranih investicija u zemlje tranzicije. Iako mnogi tranziciju smatraju dovršenom ulaskom Hrvatske u Europsku uniju, gospodarstvo koje će se temeljiti na pravoj konkurentnosti, istinski slobodnom poduzetništvu, a koje je pak u ravnovjesju sa socijalnom osjetljivosti, potrebno je tek stvoriti.
\end{abstract}

Ključne riječi: tranzicija, gospodarstvo, komunizam, demokracija, tržište

\section{Uvod - tranzicija i njezini rezultati}

Pad Berlinskog zida 1989. simbolizira početak novog, postkomunističkog razdoblja. U nizu zemalja srednje, istočne i jugoistočne Europe uslijedile su političke promjene (pad komunističkih režima). Započeo je proces tranzicije (ponekad se koristi i termin »transformacija «), tj. prijelaza iz komunističkog u novo društveno razdoblje. Na političkoj razini riječ je o prijelazu iz jednostranačkog, nedemokratskog u višestranački, demokratski sustav, a u području gospodarstva riječ je o prijelazu iz planske, centralizirane državno-vlasničke ekonomije u tržišnu, pluralističko-vlasničku ekonomiju.

Građani zemalja bivšeg komunizma očekivali su da će im tranzicija donijeti gospodarski procvat, odnosno podizanje standarda na nivo razvijenih zemalja

* Dr. sc. Predrag Haramija, Zagrebačka škola ekonomije i managementa. Adresa: Jordanovac 110, 10 000 Zagreb, Hrvatska. E-pošta: predrag.haramija@zsem.hr

** Dr. sc. Đuro Njavro, dekan Zagrebačke škole ekonomije i managementa. Adresa: Jordanovac 110, 10000 Zagreb, Hrvatska. E-pošta: dekan@zsem.hr 
Zapada. Međutim, prve godine tranzicije, od 1990. do 1993., bile su u svim zemljama obilježene izrazitom gospodarskom nestabilnošću, odnosno visokom inflacijom i recesijom. Pad BDP-a bio je znatno veći nego što se očekivalo i trajao je od 1992. do 1996. za sva gospodarstva u tranziciji, a 1994. pad BDP-a iznosio je oko $41 \%$ u odnosu na razinu 1989 . godine. ${ }^{1}$ Još je teža bila situacija u zemljama koje su bile suočene i s ratnom agresijom (Hrvatska, BiH). Nakon 1996. situacija se u tranzicijskim zemljama stabilizirala, no tek početkom i sredinom 2000-tih sve zemlje tranzicije bilježe blag gospodarski rast. Globalna financijska kriza 2008. — 2009. i kriza u Eurozoni 2011. - 2013. vrlo se snažno odrazila i na tranzicijske zemlje te one od tada ponovo gospodarski nazaduju, gospodarstvo je ponovo destabilizirano, smanjuju se stope rasta i povećava nezaposlenost. ${ }^{2}$

Do danas većina tranzicijskih zemalja nije doživjela pravi gospodarski uzlet; stanje BDP-a nije se bitnije promijenilo četvrt stoljeća. Po veličini BDP-a tranzicijske zemlje smještene su još uvijek ispod zemalja EU15 (članice Europske unije prije proširenja 2004.). Tek poneke tranzicijske zemlje prelaze polovicu BDP-a po glavi osobe tih zemalja. Jedina tranzicijska zemlja čiji je BDP po glavi stanovnika iznad Grčke, najslabije zemlje EU15, je Slovenija s 24.019 USD. Hrvatska je s 13.494 USD ispod Grčke s 21.653 USD i duplo manje od Španjolske s 30.278 USD. $^{3}$

Samo neke tranzicijske zemlje (Letonija, Estonija, Litva, Poljska, Češka i Slovačka) ostvarile su 2012. viši BDP nego što je on iznosio 23 godine prije - 1989. godine. Ostale zemlje bilježile su približno isti BDP ili niži nego 1989. godine. ${ }^{4}$

To znači da se standard stanovnika nije bitno promijenio, a uzmemo li u obzir da su cijene u tom periodu isto tako porasle, on je čak lošiji. Istodobno, dolazi i do porasta nezaposlenosti; od 1990. do 1995. ona je izravna posljedica tranzicijskih promjena, a od 2008. do 2013. vezana je uz svjetsku financijsku krizu. Ipak, nakon 2013. u mnogim zemljama tranzicije smanjuje se nezaposlenost, no neke zemlje (među njima i Hrvatska) još se bore s izuzetno visokom nezaposlenosti. ${ }^{5}$

Proces tranzicije pokazao se tegobnijim nego što su to građani bivših socijalističkih zemalja očekivali. Sve je jača diferencijacija između tankog sloja iznimno bogatih i sve šireg sloja siromašnih, uz istodobnu dekonstrukciju srednjeg sloja. Kritika tranzicije »nalazi svoju legitimaciju u činjenici masovnog osiromašenja ali i propadanja osobito srednjih slojeva ${ }^{6}{ }^{6}$

1 Usp. M. Lavigne, The Economies of Transition: From socialist economy to market economy, London, 1995.

2 Usp. International Monetary Fund, 25 Years of Transition - Post-Communist Europe and the $I M F$, Washington D. C., 2014.

3 International Monetary Fund, World Economic Outlook Database 2015. URL: https://www.imf. org/external/pubs/ft/weo/2015/02/weodata/index.aspx (preuzeto 11.03.2016.)

4 European Bank for Reconstruction and Development (EBRD), Transition Report 2013, London, 2013. URL: http://www.ebrd.com/news/publications/transition-report/transition-report-2013. html (preuzeto 11.03.2016.)

5 International Monetary Fund, 25 Years of Transition, str. 5.

6 I. Cifrić, Tranzicija i transformacija — između norme i prakse, Socijalna ekologija, 5/2 (1996), str. $135-153$ i 144. 
Istraživanja pokazuju da je u zemljama tranzicije razočarenje javnosti sve veće i da broj ljudi koji izražavaju nostalgiju za starim sustavom raste. $72 \%$ Mađara, 62 \% Ukrajinaca i Bugara, 48 \% Litvanaca i Slovaka, 45 \% Rusa, $39 \%$ Čeha i $35 \%$ Poljaka smatra da živi lošije nego u komunizmu. ${ }^{7}$

Zašto u većini zemalja tranzicija nije donijela u gospodarstvu rezultate koje je javnost očekivala? Spoznajemo da je uzrok u pet glavnih čimbenika. Prvi je loša naslijeđena struktura gospodarstva, odnosno snažan politički utjecaj na gospodarstvo. Drugi, institucionalno nasljeđe komunizma (loš rad institucija; golema i neučinkovita administracija, birokratizirani pristup, prenormiranost i korupcija). Treći, loše provedena privatizacija posljedica je prva tri. Četvrti, nedostatna pomoć Zapada odnosno šablonizirani pristup međunarodnih organizacija koje više traže kvantitetu nego kvalitetu promjena. Peti čimbenik je nerazvojni karakter stranih investicija u zemlje tranzicije.

Uz čimbenike koje smo naveli postoji i »subjektivni« čimbenik koji se nalazi u sferi kulture, odnosno svjetonazora i vrijednosti. Riječ je o sustavu vrijednosti u društvu, o svjetonazoru, mentalitetu koji se opire promjenama, otežava i usporava tranziciju. Temelj tog opiranja je ukorijenjenost kulturnog (vrijednosnog) nasljeđa komunizma. ${ }^{8}$

\section{Naslijeđena struktura gospodarstva i politički utjecaj na gospodarstvo}

Iako je komunizam bio totalitarni sustav i nije bio prilagodljiv dinamičnim promjenama suvremenog svijeta, ipak je relativno dugo opstao. Što je tomu uzrok? Smatra se da su za dugovječnost komunističkoga režima dijelom zaslužna (uz autoritarne osobine režima) upravo široka socijalna prava. Naime, radi socijalne sigurnosti koja im je bila nuđena (sigurnost radnog mjesta, socijalno osiguranje i sl.), radnici su pristajali na ograničenja drugih svojih prava (prije svega političkih), na birokratske privilegije te na relativno nizak društveni standard. ${ }^{9}$ Partijska elita »štiti« radnika i osigurava mu sigurnost posla te minimalan ali siguran dohodak. Posljedično »u praktički svim granama socijalističke privrede vrlo je velika prezaposlenost — prikrivena nezaposlenost «. ${ }^{10}$

U komunističkim zemljama politika utječe na biranje (postavljanje) direktora i na praksu upravljanja. Osnovni kriterij izbora je »moralno-politička podobnost «, a stručne sposobnosti imaju drugorazredno značenje. Za takvo upravljanje politički razlozi daleko su važniji od poslovnih razloga. Upravljački proces ne temelji se na stručnosti, nego na političkim i socijalnim konsideracijama. Sam

7 Pew Research Center - Pew Global Attitudes Project, Two Decades After the Wall's Fall, Washington D. C., 2009. URL: http://www.pewglobal.org/files/2009/11/Pew-Global-Attitudes-2009_ Pulse-of-Europe-Report-Nov-2-1030am-NOT-EMBARGOED.pdf (preuzeto 03.04.2016.)

8 Svjetonazorsko nasljeđe komunizma u nas je prvi istraživao akademik Josip Županov.

9 Usp. S. Zrinščak, Socijalna politika u kontekstu korjenite društvene transformacije postkomunističkih zemalja, Revija za socijalnu politiku, 10/2 (2003), str. 135-159.

10 Đ. Njavro, Privatizacija, Društvena istraživanja, 2/1 (1993), str. 91. 
proces donošenja odluka krajnje je kompliciran i dugotrajan, a poduzeće ne može brzo reagirati na promjene u vanjskoj okolini. Neizbježan je rezultat takvog upravljanja potpuna neefikasnost poduzeća. ${ }^{11}$

Krajem 80-tih neravnovjesja u socijalističkim gospodarstvima dosegnula su kritičnu razinu. Proračunski deficit pokrivan je tiskanjem novca. ${ }^{12}$ Inflacija je nezaustavljivo rasla, pa je 1989. dosegnula $640 \%$ u Poljskoj i nevjerojatnih $2.700 \%$ u Jugoslaviji. ${ }^{13}$ Činjenica je da su 1989. gospodarski sustavi tranzicijskih zemalja bili pred potpunim slomom. S prvim godinama tranzicije, usvajanjem tržišnih zakonitosti, sve katastrofalne gospodarske greške komunističkog sustava dolaze odjednom na naplatu.

U socijalističkim zemljama (nakon Staljinove smrti) postupno se kroz razne "privredne reforme« razvijao (kako ga naziva Josip Županov) »politički kapitalizam«. On se razlikuje od »poduzetničkog kapitalizma« koji obilježava razvijena građanska društva Zapada jer nije zasnovan na poduzetništvu, nego na legalnim i polulegalnim privilegijama. ${ }^{14}$

Kako bi lakše sagledali kako i u kojoj mjeri politika još uvijek utječe na gospodarstvo u tranzicijskim zemljama, korisno je napraviti razlikovnu tablicu političkog i poduzetničkog kapitalizma.

Tablica 1. Usporedba svojstava političkog i poduzetničkog kapitalizma

\begin{tabular}{|l|l|}
\hline Politički kapitalizam & Poduzetnički kapitalizam \\
\hline $\begin{array}{l}\text { Prevladava državno (»društveno«) } \\
\text { vlasništvo. }\end{array}$ & Prevladava privatno vlasništvo. \\
\hline $\begin{array}{l}\text { Veliki dio BDP se redistribuira u } \\
\text { državi. }\end{array}$ & $\begin{array}{l}\text { Proporcionalno manji dio BDP-a se } \\
\text { redistribuira državnim kanalima. }\end{array}$ \\
\hline $\begin{array}{l}\text { Fragmentirano tržište (tržište roba } \\
\text { i usluga) i politički lažirano tržište } \\
\text { (monopoli). }\end{array}$ & $\begin{array}{l}\text { Integrirano (svima dostupno) tržište } \\
\text { i konkurentno (mada ne uvijek u } \\
\text { potpunosti) tržište. }\end{array}$ \\
\hline $\begin{array}{l}\text { Država štiti (neka) poduzeća od } \\
\text { konkurencije i često im pokriva gubitke } \\
\text { te osigurava sigurnost radnog mjesta u } \\
\text { njima. }\end{array}$ & $\begin{array}{l}\text { Država stvara i nadzire sustav } \\
\text { pravila na tržištu koji sve aktere } \\
\text { tržišta tretira jednako i pravično. }\end{array}$ \\
\hline
\end{tabular}

11 Usp. J. Županov, Samoupravni socijalizam: konac jedne utopije, Politička misao, 26/4 (1989), str 21-36.

12 International Monetary Fund, 25 Years of Transition, str.10.

13 Vidi: F. Coricelli; R. Rezende Rocha, Stabilization Programs in Eastern Europe: A Comparative Analysis of the Polish and Yugoslav Programs of 1990, Washington D. C., 1991.

14 J. Županov, Od komunističkog pakla do divljeg kapitalizma: odabrane rasprave i eseji (1995.-2001.), Zagreb, 2002, str. 62. 


\begin{tabular}{|l|l|}
\hline $\begin{array}{l}\text { Gospodarske aktivnosti vode politički } \\
\text { menadžeri, a ne profesionalni } \\
\text { menadžeri. U političke menadžere } \\
\text { spadaju i političke funkcije u poduzeću } \\
\text { i lokalnoj samoupravi, a menadžment } \\
\text { je direktno povezan s političkom } \\
\text { hijerarhijom. }\end{array}$ & $\begin{array}{l}\text { Gospodarske aktivnosti vode } \\
\text { profesionalni menadžeri, } \\
\text { opunomoćenici dioničara i } \\
\text { individualni poduzetnici. Oni su } \\
\text { autonomni u odnosu na državnu } \\
\text { upravu. }\end{array}$ \\
\hline $\begin{array}{l}\text { Poduzeće nije profitna ustanova, nego } \\
\text { neka vrsta zajednice ili udruge, sa } \\
\text { sigurnim radnim mjestom. }\end{array}$ & $\begin{array}{l}\text { Gospodarstvo zahtijeva } \\
\text { fleksibilnost, i radnog mjesta i } \\
\text { obrazovanja }\end{array}$ \\
\hline $\begin{array}{l}\text { Natječaji su često lažirani, kandidati } \\
\text { se biraju više na temelju neformalnih } \\
\text { veza negoli na osnovi pokazanih } \\
\text { sposobnosti. Na razne društvene } \\
\text { funkcije kandidati se biraju uglavnom } \\
\text { na temelju lojalnosti vladajućoj eliti, a } \\
\text { ne pokazanih sposobnosti. }\end{array}$ & $\begin{array}{l}\text { Pri zapošljavanju provodi se } \\
\text { kompeticija prema sposobnosti. } \\
\text { Natjecanje je princip u ekonomskoj } \\
\text { i svim dugim djelatnostima, a } \\
\text { izbor na razne društvene položaje } \\
\text { provodi se na temelju demokratske } \\
\text { institucije natječaja. }\end{array}$ \\
\hline $\begin{array}{l}\text { Političke funkcije i poslovi u javnom } \\
\text { sektoru su bolje plaćeni nego u } \\
\text { privatnom. }\end{array}$ & $\begin{array}{l}\text { Poslovi u privatnom sektoru su } \\
\text { (prema spremi i sposobnosti) } \\
\text { plaćeni bolje nego u državnoj službi. }\end{array}$ \\
\hline $\begin{array}{l}\text { Znanost se ne shvaća kao gospodarski } \\
\text { razvojni resurs, marginalizacija znanosti } \\
\text { te posljedični odlazak znanstvenika u } \\
\text { inozemstvo. }\end{array}$ & $\begin{array}{l}\text { U gospodarstvu je ključna uloga } \\
\text { znanosti, bez koje nema novih } \\
\text { tehnologija i inovativnih proizvoda. } \\
\text { Znanost je razvojni resurs. }\end{array}$ \\
\hline
\end{tabular}

Razvidno je da su u tranzicijskim državama danas prisutna oba tipa kapitalizma, s predominacijom političkog. Prema Županovu čimbenici (endogeni) koji pogoduju političkomu kapitalizmu su: inercija, naslijeđeni položaji i vještine vladanja iz socijalizma, neotradicionalizam, političko kameleonstvo te (egzogeni) politička klasa kao stabilizator prostora, potrebna svjetskim moćnicima. ${ }^{15}$

Ukratko u gospodarstvu tranzicija je još daleko od dovršenja jer se političke strukture (stranke na vlasti) ne žele odreći komunističkog nasljeđa manifestiranog u vidu političkog utjecaja na gospodarstvo.

\section{Institucionalno nasljeđe komunizma}

Institucionalno nasljeđe komunizma očituje se kao golema i neučinkovita administracija, birokratizirani pristup, prenormiranost i korupcija.

Komunizam je sustav koji je nastojao regulirati svaki aspekt života i privređivanja. Državni administrativni aparat nabujao je preko svake mjere, a 
radno mjesto u državnoj upravi davalo je sigurnost i utjecaj. »Birokratizirana i restriktivna vlast otvorila je put korupciji i mitu državnih službenika jer se većini građana činilo da je to jedini put do ostvarenja željenog cilja. «16 $\mathrm{S}$ početkom tranzicije nove vlasti suočavaju se s naslijeđenom neefikasnosti administracije, pune nesposobnih službenika bivših komunističkih vlada, slabom radnom disciplinom i učestalom korupcijom.

Bujanje administracije, na žalost, ne prestaje ni tranzicijom. Tako je i u nas, u razdoblju 2006. — 2008., ukupan broj zaposlenih u hrvatskom javnom sektoru porastao s 378.000 na $388.000 .{ }^{17}$

Iako se istraživanja korupcije uglavnom temelje na percepciji javnosti o njoj, a i sam je pojam korupcije različit u različitim zemljama, ipak su indikativan pokazatelj. Po recentnim istraživanjima u tranzicijskim zemljama ona je u prosjeku veća nego u starim članicama EU. ${ }^{18}$

Povjerenje u institucije većina autora smatra ključnim za razvoj demokratske civilne i političke kulture koja podrazumijeva društvenu i političku aktivnost većine građana.

Pri dnu ljestvice raznih europskih istraživanja povjerenja u institucije u većini se nalaze uvijek tranzicijske zemlje. ${ }^{19}$ Možda je tomu tako jer je u represivnim komunističkim sustavima kod građana prevladavao strah, a ne povjerenje u institucije. Štoviše, državu i državni aparat doživljavali su kao nešto strano, nešto čije propise nije bilo nemoralno izbjegavati i zaobilaziti. ${ }^{20}$ Uočljiv je »nesklad između očekivanja građana da država bude odgovorna za njihove probleme, odnosno izrazito visokih očekivanja građana od državnih institucija, i svojstva samih tih institucija — te institucije karakterizira nekompetentnost, neefikasnost, korupcija, nepotizam i zalaganje za partikularne stranačke a ne opće interese «. ${ }^{21}$

Zemlje najvećeg povjerenja u institucije, poput Norveške, Danske, Finske, Švedske i Nizozemske, najbogatije su i najnaprednije europske zemlje. Zemlje u kojima se usmeni i pismeni ugovori poštuju, zakonski okvir je jednostavan, jasan i stabilan (ne mijenja se svaki čas), a prijevare i korupcija vrlo su rijetke, zemlje su u kojima postoji atmosfera sigurnosti i stabilnosti. U takvim zemljama lakše je

16 V. Dimitrova Grajzl; E. Simon, Political Trust and Historical Legacy, East European Politics and Societes, 24/2 (2010), 206-228.

17 Vidi: P. Bejaković, Zaposlenost u javnoj upravi: stanje, problemi i reforme u Hrvatskoj i svijetu, 6. Forum za jаvnu upravu, Zagreb, 2014, str. 31-51. URL: https://bib.irb.hr/datoteka/697626.predrag.pdf (preuzeto 23.04.2016.)

18 European Parliamentary Research Service - RAND Europe, The Cost of Non-Europe in the area of Organised Crime and Corruption, Brussels, 2016; Transparency International, Corruption perception index 2015. URL: http://www.transparency.org/cpi2015 (preuzeto 11.03.2016.)

19 C. Bjornskov, Determinants of generalised trust: A cross-country comparison, Public Choice, 130 (2006); J. Baloban i dr., Vrednote u Hrvatskoj i u Europi, Kršćanska sadašnjost, Zagreb, 2014; Lj. Kaliterna Lipovčan i dr., Eurofound — Trendovi u kvaliteti života — Hrvatska: 2007. — 2012. Luxembourg, 2014.

20 Usp. V. Dimitrova Grajzl - E. Simon, Political Trust and Historical Legacy, 206-228.

21 K. Nikodem — G. Črpić, O (ne)održivosti veza između povjerenja i demokracije — analiza povjerenja u institucije u Hrvatskoj i u Europi, u: J. Baloban i dr., Vrednote u Hrvatskoj i u Europi, Zagreb, 2014, str. 268. 
poslovati, kamate su niske i gospodarstvo napreduje. Nasuprot tomu, u zemljama niskog povjerenja ne može se računati na dobru namjeru i poštenje te država ima potrebu sve normirati i pokriti zakonima. U zemljama u kojima država ne vjeruje građanima a građani ne vjeruju državi ni za jednu mjeru ili zakon ne možete biti sigurni da će potrajati duže od mandata vlade, ne postoje jasne okosnice na kojima građani mogu planirati svoj život.

U Hrvatskoj svjedočimo opetovanomu »reformiranju « sustava bez jasnih ciljeva i razloga. Prevladava naglasak na stalnim promjenama institucionalnog okvira, što postaje sve pogubnije za većinu građana. ${ }^{22}$ Novi zakoni donose se bez razmišljanja o njihovu provođenju, nisu usklađeni i sadrže manjkavosti. U Hrvatskoj udruzi poslodavaca ističu kako »u Hrvatskoj postoji 15000 raznih odredbi kojima se kažnjavaju poduzetnici «. ${ }^{23} \mathrm{U}$ takvoj šumi propisa ni sudovi se ne mogu snaći. Bez jednostavnih i jasnih propisa, jasnih dugoročnih strategija i učinkovite koordinacije nema pomaka naprijed. ${ }^{24}$ Međunarodna istraživanja poduzetničke aktivnosti kao najveće ograničenje u stvaranju stimulirajuće poduzetničke okoline $\mathrm{u}$ nas vide prenormiranost. odnosno nepostojanje djelotvorne vladine politike prema pojednostavljenju regulatorne okoline. ${ }^{25}$

\section{Način provedbe privatizacije}

Privatizacija je u brojnim zemljama (a jedna od njih je i Hrvatska) počela još i prije pada komunizma. Suočene s teškom gospodarskom situacijom, sve su zemlje Istočne i Srednje Europe krenule krajem 80-ih godina u proces privatizacije.

Kroz privatizaciju državnih tvrtki tranzicijske zemlje nadale su se da će moći financirati javne potrebe. Kako privatizacija nije donijela očekivani prihod (ni očekivani zamah gospodarstvu), zemlje tranzicije bile su prisiljene na nova zaduživanja — gomila se javni dug.

Kako je ustvari tekao sam proces privatizacije i tko je najviše profitirao u njemu jasno razotkriva niz autora iz zapadnih zemalja. Navode da privatizaciju ponajprije provodi komunistička nomenklatura, pri čemu se bivše komunističke partije iznenađujuće brzo transformiraju u glasne pobornike neoliberalnog modela socijaldemokracije. Sve počinje i prije 1989. kad direktori poduzeća zlorabe kontrolu koju imaju nad poduzećima kako bi ih pretvorili u privatno vlasništvo. To postižu preusmjeravanjem novca u privatne tvrtke i rasprodajom imovine državnih poduzeća. Pritom im pomaže posjedovanje povlaštenih informacija te

22 Isto, str. 271.

23 Usp. M. Šunjerga, Vlada guši biznis, regulative previše a primjena loša, Poslovni dnevnik, 19.04.2016., str. 1.

24 Usp. K. Ott, Kriza u jugoistočnoj Europi — slučaj Hrvatske, Institut za javne financije — odabrani prijevodi, Zagreb, 6/11 (2011). URL: http://www.ijf.hr/OP/6.pdf (preuzeto 21.04.2016.)

25 Vidi: Global Entrepreneurship Monitor (GEM), Country Profiles — Croatia. URL: http://www. gemconsortium.org/country-profile/54 (preuzeto 11.05.2016.) 
politička zaštita i povezanost sa sigurnosnim službama, kao i sama prednost što su prvi krenuli u akciju. ${ }^{26}$

Strategije privatizacije razlikovale su se od države do države. Program privatizacije u Ukrajini bio je naklonjen lokalnim interesima, a neprijateljski raspoložen prema stranim investitorima, posebice u »strateškim « industrijama. U Mađarskoj od 1988. rukovodstvo poduzeća iskoristilo je priliku ili da prisvoji dio tvrtke ili da uđe u partnerstvo sa stranom tvrtkom. ${ }^{27}$ Glavna metoda privatizacije u Poljskoj bili su otkupi poduzeća od strane direktora. Češka se odlučila za relativno brzu metodu kuponske privatizacije, pri čemu su propisi davali prednost osobama izvan samog poduzeća (premda ne i inozemnim ulagačima). Suprotno očekivanjima, većinu kupona razgrabilo je nekoliko privatizacijskih investicijskih fondova, od kojih su mnogi podvrgnuti de facto nacionalizaciji nakon što nisu mogli otplatiti kredite državnim bankama. Te iste banke kasnije su rasprodane inozemnim financijskim institucijama. ${ }^{28}$ Rusiji je svojstvena sprega državne birokracije (koja je preživjela tranziciju gotovo netaknuta) i u privatizaciji stvorenih novih poslovnih moćnika oligarha, koji velik utjecaj nad Rusijom gube tek Putinovim dolaskom na vlast 2000. godine. ${ }^{29}$

$\mathrm{Na}$ proces privatizacije u zemljama bivše Jugoslavije utjecao je i naslijeđeni oblik samoupravnog socijalizma. Naime, radnici »samoupravljači« često se odupiru predavanju kontrole vanjskim investitorima i time ustvari olakšavaju komunističkim direktorima preuzimanje tvrtki. Ipak, proces privatizacije $\mathrm{u} \mathrm{Hr}$ vatskoj i Sloveniji razlikuje se. U Sloveniji je privatizacija provedena znatno opreznije i sveukupno je privatizirano znatno manje. U Sloveniji se odmah po odcjepljenju od Jugoslavije proces privatizacije zaustavio, i tek nakon dvije godine javne rasprave Vlada je donijela novi zakon. Paralelno s usvajanjem tog zakona, građanima su podijeljeni vaučeri koji su mogli biti uloženi u poduzeća ili u različite državne fondove. Treba spomenuti da slovenski Zakon o privatizaciji nalaže školovanje posebnih revizora za vrednovanje društvene imovine. Privatizacija u Hrvatskoj provodila se u okolnostima rata, kad teško da se mogla odvijati transparentno. Prodaja bivših društvenih poduzeća ponajprije zaposlenima (radnicima i menadžerima), a zatim ulagačima izvan poduzeća, temeljno je načelo hrvatskog modela privatizacije. Međutim, u poduzećima (slično kao i u drugim zemljama bivšeg komunizma) ključne upravljačke, ekonomske i »poznaničke« veze imali su bivši socijalistički direktori — tako su oni postali i glavni akteri privatizacije. Iako je model privatizacije pretpostavio jednakost

26 G. Lawson (ur.), The Global 1989: Continuity and Change in World Politics, Cambridge, 2010; J. Higley i dr., The Persistence of Communist Elites, Journal of Democracy, 7/2 (1996), str. 137; S. Pirani, Change in Putin's Russia: Power, Money and People, London, 2009; G. Dale, Tranzicija u Srednjoj i Istočnoj Europi, Diskrepancija, 13 (2014), str. 19.

27 Đ. Njavro, Privatizacija, Društvena istraživanja, 2/1 (1993), str. 91.

28 Usp. J. Drahokoupil, Globalization and the State in Central and Eastern Europe: The Politics of Foreign Direct Investment, London, 2009; N. Genov, Global Trends in Eastern Europe, Aldershot, 2010.

29 Usp. R. Sakwa, The Crisis of Russian Democracy: The Dual State, Factionalism and the Medvedev Succession, Cambridge, 2011. 
svih, ubrzo je postalo jasno da realna ekonomska i upravljačka moć pretvara direktore/menadžere u jedine realne privatizacijske partnere novoj političkoj eliti i vanjskim ulagačima. ${ }^{30}$

Kako su novivlasnici težili špekulativnom stjecanju imovine, a ne poduzetništvu i stvaranju novih vrijednosti, u nizu zemalja propala su brojna poduzeća i radnici su ostali bez posla, a nova radna mjesta nisu otvorena. ${ }^{31}$ Socijalno nezadovoljstvo je raslo i posljedično u brojnim zemljama sredinom 90-tih (»reformirani«) komunisti ponovo su došli na vlast.

Sva hrvatska istraživanja percepcije javnosti o privatizaciji pokazuju negativan stav. ${ }^{32}$ Navodi se da je više od $68 \%$ ispitanika nezadovoljno (djelomično ili potpuno) dotadašnjim tijekom privatizacije. ${ }^{33}$ Po mišljenju javnosti, krajnji učinak privatizacije stvaranje je poslovnih carstava nekolicine tajkuna na štetu zaposlenika i ostalih građana, a modernizacija društva, tržišna privreda i povećanje efikasnosti poduzeća nisu uopće ostvareni. ${ }^{34}$ Građani smatraju da je trebalo podijeliti ili uz popust prodati javna dobra radnicima i svim građanima, a ne prodavati uz popuste ili dodjeljivati manjinskoj političkoj eliti i direktorima privatiziranih poduzeća, kako je učinjeno. Samo $15 \%$ građana Hrvatske smatra privatizirana poduzeća uspješnijima od onih u državnom vlasništvu. ${ }^{35}$

Temeljna je postavka koja sugerira potrebu za privatizacijom da će privatni vlasnik (ili vlasnici) bolje, tj. uspješnije, voditi poduzeće nego država, zato što ima izravni interes da poduzeće kojega je vlasnik ostvaruje profit, te da će država prodajom poduzeća doći do potrebnih financijskih sredstava. Zato bi, želimo li ocijeniti uspješnost privatizacije, to ponajprije trebalo učiniti kroz dva glavna pitanja. Prvo, je li privatizacijom poduzeće završilo u vlasništvu osobe željne i sposobne razviti ga? Drugo, je li privatizacijom poduzeća država dobila odgovarajuću financijsku protuvrijednost? Nažalost, u slučaju Hrvatske, a i više tranzicijskih zemalja, odgovor na ta dva pitanja često je — ne.

\section{Neadekvatna pomoć Zapada}

Početkom 90-tih sve tranzicijske zemlje našle su se u dubokoj recesiji. Nadale su se financijskoj pomoći Zapada kako bi prebrodile teškoće. Međutim,

30 Usp. Đ. Njavro, Privatizacija, Društvena istraživanja, 2/1 (1993); N. Čučković, Temeljna ekonomska obilježja hrvatskog koncepta privatizacije, u: I. Rogić - Z. Zeman, Privatizacija i modernizacija, Zagreb, 1998; D. Čengić, Vladajuća elita i proces delegitimacije privatizacijskog projekta: Ima li pouka za budućnost?, Društvena istraživanja, 9(2000), str. 4-5.

31 Š. Šokčević - V. Dugalić, Privatizacija društvenog / državnog vlasništva - (ne)uspjeli tranzicijski proces? Socijalno-etička prosudba, Diacovensia, 15/1 (2007), 146-149.

32 Usp. V. Šakić, Privatizacija pred očima hrvatske javnosti, u: S. Baloban (ur.), Gospodarsko-socijalni izazovi u tranzicijskim zemljama, Zagreb, 2001.

33 Usp. Hrvatski centar strategijskih istraživanja, Privatizacija u očima hrvatske javnosti, Zagreb, 1998, str. 14.

34 K. Peračković, Razlike u stavovima o krajnjim učincima privatizacije u Hrvatskoj, Društvena istraživanja, 9/4-5 (2000), str. 527-543.

35 Š. Šokčević - V. Dugalić, Privatizacija društvenog / državnog vlasništva, str. 103-154. 
očekivanja da će financijska pomoć biti nalik onoj koju je dobila zapadna Europa poslije Drugog svjetskog rata bila su naivna. Zapadnoj je Europi nakon 1945. godine u poslijeratnoj rekonstrukciji pomogao nagli rast svjetskog gospodarstva i Marshallov plan. Zemlje bivšeg komunizma započele su tranziciju u posve drugim okolnostima. Američko i europsko gospodarstvo više nije bilo u uzletu, a plana poput Marshalova nema (što i ne čudi jer raspadom SSSR-a nestao i geopolitički interes SAD-a za takav plan). ${ }^{36}$ Dok je $90 \%$ Marshallova plana bilo u obliku novčane potpore, u slučaju postkomunističke Europe financijska potpora početkom 90 -ih iznosila je samo oko $10 \% .{ }^{37}$ Pomoć je tranzicijskim zemljama ponajviše bila savjetodavne, stručne naravi.

$\mathrm{Tu}$ »stručnu pomoć« pružaju velike međunarodne organizacije koje i osiguravaju potrebne kredite (primjerice Svjetska banka i Međunarodni monetarni fond - MMF) ili organizacije EU (Europska banka za obnovu i razvoj - EBRD, Europska centralna banka ECB, Europska investicijska banka EIB). Stručnjaci iz Svjetske banke i MMF-a pristupaju u cijeloj Srednjoj i Istočnoj Europi šabloniziranim planom koji sadržava dva glavna elementa: »stabilizacijske programe « i »strukturne mjere«. Stabilizacijski programi bili su usredotočeni na liberalizaciju cijena i vanjske trgovine te na restriktivne fiskalne i dohodovne politike s ciljem smanjenja državne potrošnje i snižavanja plaća. Strukturne mjere uključivale su privatizaciju, bankovnu reformu te rezove u industrijskoj politici i socijalnoj skrbi. ${ }^{38}$ Ima stajališta da u svemu postoji i doza ekonomske prisile. Naime, dobivanje (tako potrebnih) zajmova uvjetuje se striktnom provedbom tih mjera (najčešće onih štednje i brze privatizacije). ${ }^{39}$

EU putem programa Phare, koristeći uvjetovanje članstva u Europskoj uniji kao poticaj, tjera zemlje koje su željele postati članice na prilagođavanje politika državne potpore i tržišnog natjecanja pravilima Europske unije, odnosno na liberalizaciju trgovine i investicija na način koji otežava udovoljavanje zahtjevima za protekcionizmom. ${ }^{40}$

Međunarodne organizacije za ispomoć u provedbi svojih programa angažiraju mnoštvo profesionalnih savjetnika, konzultanata (ponajviše iz SAD-a, Velike Britanije i Švedske), koji dolaze u tranzicijske zemlje. ${ }^{41}$ Usluge tih savjetnika

36 Marshallov plan nije bio samo pomoć izgradnji uništenih ratnih područja, nego mu je cilj bio i spriječiti sovjetski utjecaj. Osim toga, uvelike je poticao industriju SAD-a jer novac iz Marshallova plana, koji je odlazio u Europu također se koristio za europsku kupnju američkih i kanadskih proizvoda. Novac koji je Jugoslavija počela dobivati 1949. i u većim iznosu od 1950. do 1953. nije bio sasvim povezan s Marshallovim planom, ali je reflektirao sukob sa SSSR-om i politiku SAD-a da se Jugoslavija održi.

37 Usp. W. Outhwaite, What is Left after 1989?, u: G. Lawson - C. Armbruster i M. Cox (ur.), The Global 1989: Continuity and Change in World Politics, Cambridge, 2010, str. 92.

38 Usp. M. Lavigne, nav. dj., str. 117-119.

39 Usp. G. Dale, nav. dj., str. 88.

40 Usp. J. Hardy, Crisis and Recession in Central and Eastern Europe, International Socialism, 128 (2010). URL: http://isj.org.uk/crisis-and-recession-in-central-and-eastern-europe/ (preuzeto 18.04.2016.)

41 Profesionalni savjetnici dolaze iz sljedećih tvrtki: Agriconsulting, Atos, COWI, Ernst \& Young, GOPA, GTZ, Human Dynamics, Idom, IMC Consulting, Louis Berger, NIRAS, PA Consulting, PE International, Pohl Consulting, PwC i SOFRECO. 
plaćaju se iz sredstava koje zemlje tranzicije dobivaju za provedbu programa restrukturiranja, te ponekad odnose veći dio tih sredstava. ${ }^{42}$

Pretpostavljalo se da ce kombinacija stabilizacijske i strukturne reforme omogućiti brzu i uspješnu tranziciju, a liberalizacija trgovine omogućiti priljev kapitala, što će zauzvrat izazvati nagli rast potaknut izvozom, a niske plaće i blizina tržišta Europske unije osigurati konkurentsku prednost. Kako se državni sektor bude smanjivao, nova mala poduzeća popunit će tu prazninu i preuzeti dio posla, osiguravajući tako radna mjesta za nezaposlene. Međutim, zbog zastarjelih tehnologija, loše kvalitete mnogih proizvoda te slabih distribucijskih i marketinških mreža, malo se koji proizvođač iz tranzicijskih zemalja uspio probiti na vanjska tržišta, a protekcionizam velikih sila (Europske unije i Sjeverne Amerike) dodatno je otežavao situaciju.

Učinak takvih šabloniziranih tranzicijskih strategija već se u kratkom roku pokazao destabilizirajućim za zemlje u kojima se primjenjuju. Usprkos tomu, najčešći odgovor međunarodnih organizacija na pitanje zašto tranzicija ne donosi očekivani gospodarski napredak bio je, sažeto rečeno, neprovođenje reformi (koje sugeriraju). Pritom ne daju jasan odgovor na pitanje zašto su neke zemlje (poput Slovenije) koje su se suprostavile nekim sugeriranim reformama ujedno i zemlje najvišeg standarda (među tranzicijskim zemljama).

Međunarodne organizacije i organizacije EU, kad mjere napredak tranzicije u nekoj zemlji, ponajprije nastoje izmjeriti u kolikoj su mjeri provedene reforme koje traže. ${ }^{43}$ Traže se uvijek iste reforme, a pritom ne sagledavaju razlike i specifičnosti pojedinih zemalja. Slikovito rečeno - isti broj cipela nastoji se navući na različite noge. Pritom su usmjerene na kvantitetu promjena, a ne gledaju toliko njihov kvalitetu.

\section{Nerazvojni karakter stranih investicija}

Tranzicijske zemlje nadaju se i stranim investicijama u svoja gospodarstva. Ponajprije bi trebale biti dobrodošle one koje otvaraju nova poduzeća, nova radna mjesta. Strane investicije i dolaze, međutim nisu tako oblikovane da potiču zapošljavanje (radna snaga je jeftinija u Azijskim zemljama). U većini slučajeva stranim privatnim poduzećima omogućava se da na već postojećoj javnoj infrastrukturi stvaraju profit. ${ }^{44}$ Vrlo malo je tzv. greenfield investicija.

Najučestalije su investicije u financijski sektor. U mnogim zemljama tranzicije skoro cijeli bankarski sustav odlazi u vlasništvo stranih (većinom zapadnoeuropskih) banaka. Znamo li da je bankarski sektor glavna financijska poluga za

42 M. Lavigne, nav. dj.

43 I MMF i EBRD u popisu najvažnijih reformi od početka tranzicije navode sljedeće: privatizacija, restrukturiranje državne uprave i poduzeća, slobodno formiranje cijena, slobodna trgovinska razmjena (s inozemstvom), promicanje kompetitivnosti, reforme banaka i slobodno formiranje kamata, reforme infrastrukture.

44 Ilustrativan je slučaj privatizacija HT-a (Hrvatski telekom) u nas početkom 2000-ih. 
upravljanje nekim gospodarstvom, stvari postaju jasnije. Evo kako izgleda postotak imovine (ukupne, bankovne) u vlasništvu stranih banaka: Slovačka $99 \%$, Estonija $98 \%$, Hrvatska $94 \%$, Litva $90 \%$, Bugarska $85 \%$, Češka $85 \%$, Poljska $75 \%$, Srbija $75 \%$, Mađarska $65 \%$, Latvija $65 \% .{ }^{45}$

I opet je zanimljivo usporediti Hrvatsku i Sloveniju. Iako je gotovo deset godina prije Hrvatske ušla u EU, Slovenija se u više poteza suprotstavila MMF-u i organizacijama EU. Do 2015. izravna inozemna ulaganja u Hrvatsku iznosila su 30,07 milijardi eura, ${ }^{46}$ a u Sloveniju su bila tri puta manja, ukupno manje od 10 milijardi eura. Tako su i banke ostale većinom u slovenskom vlasništvu, samo ih je oko 30 \% u stranom vlasništvu. U Hrvatskoj je krajem 1998. samo 6,7 \% banaka bilo u stranom vlasništvu. Predsjednik Tuđman protivio se rasprodaji hrvatskih banaka strancima, no već 2000. strancima je prodano 44,2\% ukupnog hrvatskog bankarstva, a do kraja 2003. godine 90,4\%. Danas je oko $94 \%$ banaka u stranim rukama. ${ }^{47}$

Izgleda da strane investicije nisu donijele prosperitet stanovništvu zemalja u koje su dolazile. U brojnim tranzicijskim zemljama idealiziralo ih se i nije spoznavalo da strane investicije ne moraju značiti opći razvitak društva ili države. Standard građana i priljev direktnih stranih ulaganja često nisu proporcionalni. Tijekom 2003. vrijednost stranih ulaganja izražena u postotku BDP-a bila je izrazito velika u Mađarskoj (58 \%) i Češkoj (50 \%), ali relativno mala u Poljskoj $(27 \%)$ i Sloveniji $(16 \%) .{ }^{48}$ Usporedimo li navedeno s iznosom prosječnih plaća, gotovo da možemo govoriti o pravilu — što više stranih investicija, to manje plaće. Slovenija, koja ima najviše plaće od zemalja tranzicije (1.092 EUR), ima i najveći broj tvrtki u domaćem vlasništvu. Mađarska, koja je imala znatno veći udio stranih investicija od Slovenije, ima dvostruko nižu prosječnu plaću (560 EUR). Češka i Slovačka s puno stranih investicija imaju manje plaće (754 EUR, odnosno708 EUR). Hrvatska im je slična s prosječnom plaćom od 742 EUR. Poljska pak s relativno malo stranih investicija ima veći prosjek plaća (756 EUR).

\section{Zaključak}

Pri stvaranju planova tranzicije u nedovoljnoj se mjeri posvećivala pozornost naslijeđenoj lošoj strukturi gospodarstva, šteti od političkog utjecaja na gospodarstvo i institucionalnog nasljeđa komunizma. Ti čimbenici doveli su

45 Usp. M. Pradeep - M. Selowsky - J. Zalduendo, Turmoil at Twenty: Recession, Recovery and Reform in Central and Eastern Europe and the Former Soviet Union, Washington D. C., 2010, str. 50.

46 Hrvatska narodna banka, Inozemna izravna ulaganja, 2016. URL: https://www.hnb.hr/statistika/ statisticki-podaci/sektor-inozemstva/inozemna-izravna-ulaganja (preuzeto 05.05. 2016.)

47 Vidi: J. Radojčić, Hrvatska u stranom vlasništvu, Aurora, 21. srpnja 2013. URL: http://www.aurora.hr/2186/hrvatska-u-stranom-vlasnistvu/ (preuzeto 25.03.2016.); M. Živković, Novac nema, ali bankari imaju domovinu, Dom i svijet: informativni tjedni prilog za iseljenike, 364 (2001) (10. prosinca). URL: http://www.hic.hr/dom/364/dom06.htm (preuzeto 28.03.2016.)

48 Usp. N. Bandelj, From Communists to Foreign Capitalists: The Social Foundations of Foreign Direct Investment in Postsocialist Europe, Princeton, 2008, str. 115. 
do loše provedbe privatizacije i općenito stvorili klimu koja je nepovoljna za razvoj poduzetništva. Nedovoljno poznavanje tih čimbenika pomoć Zapada čini neodgovarajućom, a nerazvojni karakter stranih investicija u zemlje tranzicije samo otežava stanje.

Izgleda da je bilo potrebno proći četvrt stoljeća da bi i velike međunarodne organizacije shvatile u čemu je pogreška. MMF danas upozorava da u svim tranzicijskim zemljama posljednjih nekoliko godina dolazi do zastoja u provedbi reformi, a u nekim se čak teži povratku na staro. Navodi da je liberalizacija trgovine i cijena brzo provedena, ali institucionalne reforme u područjima poput državne uprave, konkurentnosti, tržišta rada, privatizacije i restrukturiranja poduzeća još uvijek nailaze na otpore. Zaključuje da je izgradnja institucija nedovršena jer »predstavlja izazov za interese određenih skupina $\ll .{ }^{49}$ Kako bi se izišlo iz zastoja tranzicije EBRD predlaže i dvije mjere koje prije nismo uočili. Smatraju da treba olakša pristup (tranzicijskih) zemalja jedinstvenomu tržištu Europske unije te da treba više ulagati u ljudski kapital, posebice putem poboljšanja kvalitete visokog školstva. ${ }^{50}$

Upravljačke strukture u tranzicijskim zemljama nisu (ili nisu htjele) shvatiti da nije bilo dovoljno samo slijediti smjernice međunarodnih organizacija, tj. promijeniti zakone, odnosno donijeti niz novih, nego je trebalo stvoriti efikasniji birokratski aparat imun na mito i korupciju. Trebalo je stvoriti i novu upravljačku strukturu u gospodarstvu (školovane menadžere), odnosno (administrativno) okružje koje pogoduje privatnomu poduzetništvu i pravoj tržišnoj konkurenciji. Nisu shvatile ni da se sredstva potrebna za cjeloviti sustav socijalne zaštite ne mogu osigurati kroz hipertrofiju fiskalnih i parafiskalnih nameta, nego samo kroz stimulirajuću poreznu politiku koja će pomoći razvitku gospodarstva.

S obzirom na navedene okolnosti, tranzicija gospodarstva teško da je mogla proći drugačije, odnosno ostvariti rezultate koji je javnost zemalja bivšeg komunizma očekivala. Gospodarstvo koje ce se temeljiti na pravoj konkurentnosti, istinski slobodnomu poduzetništvu, a koje je pak u skladu sa socijalnom osjetljivosti, tek treba stvoriti. Tako će se moći uz rast gospodarstva (rast BDP-a) gledati i rast zadovoljstva građana.

49 International Monetary Fund, 25 Years of Transition.

50 EBRD, Transition Report 2013, London, 2013. 
The Transition and its Results - Why the Transition from the Communist to the Democratic System of a Market Economy did not Meet Expectations

Predrag Haramija*, Đuro Njavro**

Summary

The failure of the transition from the Communist to the Democratic political system to bring desired results in the economic domain was cause by five factors: (1) the inherited economic structure, i.e., the influence of politics on the economy; (2) the institutional heritage of Communism (huge and ineffective administration, bureaucratized approach, excessive norming and corruption; (3) poorly implemented privatization; (4) insufficient aid from the West, i.e., stereotyped approach by international organizations; (5) non-developmental aims of foreign investors in transition countries. Though many consider the transition to be complete with the entrance of Croatia into the European Union, Croatia has yet to create an economy based on real competition - a true free entrepreneurship balanced with social sensitivity.

Key words: transition, economy, Communism, Democracy, market

* Predrag Haramija, Ph.D., The Zagreb School of Economics and Management. Address: Jordanovac 110, 10000 Zagreb, Croatia. E-mail: predrag.haramija@zsem.hr

** Đuro Njavro, Ph.D., Dean of the Zagreb School of Economics and Management. Address: Jordanovac 110, 10000 Zagreb, Croatia. E-mail: dekan@zsem.hr 